\title{
Handbook of Florida Water Regulation: Clean Water Act ${ }^{1}$
}

\author{
Michael T. Olexa, Luke D'Isernia, Laura Minton, Dulcy Miller, and Sarah Corbett ${ }^{2}$
}

\section{Preface}

This handbook is designed to provide an accurate, current, and authoritative summary of the principle Federal and Florida laws that directly or indirectly relate to agriculture. This handbook should provide a basic overview of the many rights and responsibilities that farmers and farmland owners have under both Federal and Florida laws as well as the appropriate contact information to obtain more detailed information. However, the reader should be aware that because the laws, administrative rulings, and court decisions on which this handbook is based are subject to constant revision, portions of this publication could become outdated at anytime.

Several details of cited laws are also left out due to space limitations.

This handbook is distributed with the understanding that the authors are not engaged in rendering legal or other professional advice, and the information contained herein should not be regarded as a substitute for professional advice. This handbook is not all inclusive in providing information to achieve compliance with the Federal and Florida laws and regulations governing water protection. For these reasons, the use of these materials by any person constitutes an agreement to hold harmless the authors, the Florida Cooperative Extension Service, the Institute of Food and Agricultural Sciences, and the University of Florida for any liability claims, damages, or expenses that may be incurred by any person as a result of reference to or reliance on the information contained in this handbook.

\section{Clean Water Act Overview}

The Clean Water Act is directed at maintaining and restoring the chemical, physicial, and biological integrity of navigable waters, which are broadly defined as all waters of the United States. These include the following:

- Territorial seas and larger bodies of water.

- Lakes, streams, rivers, ponds, and other small water bodies if they have even a remote potential to affect interstate commerce or people involved in interstate commerce.

- Wetlands which are generally defined as lands that are covered periodically with enough water

1. This is EDIS document FE582, a publication of the Food and Resource Economics Department, Florida Cooperative Extension Service, Institute of Food and Agricultural Sciences, University of Florida, Gainesville, FL. Published December 2005. Please visit the EDIS website at http://edis.ifas.ufl.edu.

2. Michael T. Olexa, Professor, Food and Resource Economics Department, Florida Cooperative Extension Service, Institute of Food and Agricultural Sciences, University of Florida, Gainesville, FL; Director, Agricultural Law Center, University of Florida, Gainesville, FL; and Chair, Agricultural Law Committee of The Florida Bar. Luke D'Isernia, former student (graduated cum laude in 2005), Levin College of Law, University of Florida, Gainesville, FL. Laura Minton, Attorney, Dean, Mead, Egerton, Bloodworth, Capouano, and Bozarth, Orlando, FL. Dulcy Miller, attorney, Foley and Lardner, LLP, Orlando, FL. Sarah Corbett, Attorney, Florida Second District Court of Appeal, Lakeland, FL.

The Institute of Food and Agricultural Sciences (IFAS) is an Equal Opportunity Institution authorized to provide research, educational information and other services only to individuals and institutions that function with non-discrimination with respect to race, creed, color, religion, age, disability, sex, sexual orientation, marital status, national origin, political opinions or affiliations. U.S. Department of Agriculture, Cooperative Extension Service, University of Florida, IFAS, Florida A. \& M. University Cooperative Extension Program, and Boards of County Commissioners Cooperating. Larry Arrington, Dean 
to support vegetation especially suited to a wetlands environment.

Primarily through its discharge permitting requirements, the Clean Water Act limits the amounts of pollutants that may be released into these waters in an attempt to keep the water at a level safe for swimming and other uses, as well as for fish and aquatic life.

\section{Who Enforces the Clean Water Act?}

The Clean Water Act, in general, is enforced by the Environmental Protection Agency (EPA), but dredge and fill permitting is enforced by the Army Corps of Engineers. The EPA has established national standards for the maximum amount of pollutants that may be released under its permits. States are authorized under the Clean Water Act to establish their own standards for allowable levels of pollutants, as long as such standards are at least as stringent as those mandated by the EPA. The state may also be delegated permitting authority by the EPA. Currently, Florida has been delegated enforcement of only portions of the Clean Water Act (National Pollutant Discharge Elimination System permitting is still conducted by the EPA).

\section{How Is the Clean Water Act Enforced?}

National Pollutant Discharge Elimination System (NPDES) permits are the main avenue for the enforcement of the Clean Water Act. These permits specify the following:

- The amount and concentration of pollutants the holder is authorized to discharge.

- The schedules directing when compliance must be achieved.

- The requirements for testing, and monthly or quarterly reporting to the permitting authority.

\section{What Are Point Sources and Nonpoint Sources?}

The Clean Water Act requires all operators of point sources of pollution to get permits. A "point source" is any discernable, confined, and measurable conveyance from which a pollutant is or may be discharged. A point source may be a ditch or pipe discharging pollutants, a container being rinsed of pollutants, or any other source that releases pollutants into a specific area. For instance, a ditch containing fertilizers or pesticides entering navigable waterways is a point source of pollution, and is subject to the permitting requirements of the Clean Water Act. Agricultural stormwater discharges and return flow (also called "nonpoint sources") from agricultural irrigation systems are not point sources, however, and are therefore not covered by the Clean Water Act (see FE617, Notes and Glossary, for a definition of nonpoint sources).

Runoff from non-point sources, especially agricultural non-point sources, is a major source of pollution of the wetlands and waters of Florida. Runoff from non-point sources containing, among other things, pesticides, animal wastes, nutrients (such as phosphorus), and other pollutants is a major contributor of the pollution which is addressed in some of the federal and state acts and programs discussed in this handbook.

The NPDES permits impose two types of limitations on point-source polluters:

1. Technology-Based Effluent Limitations. Limits placed upon the contents of the effluent based upon the best practicable treatment technology currently available.

2. Water-Quality-Based Effluent Limitations. These limits depend upon the standards established for the quality of the water body (including groundwater bodies) into which the discharge takes place. These cases are viewed on a case-by-case basis.

\section{What About Dredge and Fill?}

The Clean Water Act requires separate permits for the discharge of dredge and fill material into navigable waters or wetlands. Dredge and fill permits are issued by the Army Corps of Engineers (ACE), but the EPA has veto power over ACE issued permits. The EPA may enforce permits issued by the ACE or when delegated to a state. 


\section{What About Oil and Hazardous Substances?}

The Clean Water Act also prohibits discharges of oil or specified hazardous substances. It further requires that all spills be reported immediately if the amount spilled is greater than the individual "reportable quantities" that the EPA has specified for each of some 300 designated "hazardous substances." Reporting spills to the Emergency Superfund Branch (see FE615, Appendix, for telephone numbers) quickly insulates the offender from criminal prosecution, but not from civil liability. It also provides for the development of a National Contingency Plan in order to efficiently remove spills.

\section{What Are the Penalties?}

The extent of criminal liability under the Clean Water Act depends primarily upon whether the violator is simply negligent (with fines up to $\$ 25,000$ per day and/or one-year imprisonment, doubled if this is offender's second violation), knows of his violation $(\$ 50,000$ per day and three-years imprisonment), or knowingly places others in serious imminent danger ( $\$ 250,000$ and/or 15-years imprisonment). All these penalties may be doubled for subsequent violations, and some may be greater for corporations.

The Clean Water Act also provides for civil and administrative penalties for each violation of the Clean Water Act or an NPDES permit. Civil penalties can be imposed for up to $\$ 25,000$ per day for each violation. Administrative penalties can be imposed for up to $\$ 125,000$. Injunctive relief (which forces violators to cease polluting) or other court-ordered relief is also available.

\section{Source}

33 United States Code, Sections 1251 to 1387

\section{Acknowledgments}

The authors are indebted to the personnel of both state and federal agencies who provided their time and advice in the preparation of this handbook. The authors are especially indebted to Richard Budell of the Office of Agricultural Water Policy of the Florida Department of Agriculture and Consumer Services for providing funds for the development of this publication. 